\title{
Conceptualizing a value-based communication system: Towards a synergy between Hindu and Islamic perspectives
}

Kapil Kumar Bhattacharyya

\author{
Correspondence: \\ kapilkrbhattacharyya@gmail.com \\ Junior Research Fellow/ PhD \\ Research Scholar (Indian \\ Communication Thought) Centre \\ for Journalism \& Mass \\ Communication, Visva-Bharati, PO: \\ Santiniketan, India
}

\begin{abstract}
Communication forms the back-bone of the modern day information revolution. However, with the present age of information revolution being plagued by issues of materialism, consumerism and power struggles, human race finds itself in a helpless situation where it can neither do away with technological innovations nor control its adverse effects. Under such circumstances, the understanding and implementation of a value-based communication system remains our only hope. This paper is a small endeavour towards the conceptualization of such an order by drawing a synergy between the respective perspectives on human communication that two world religions, Hinduism and Islam, offer towards the survival, sustenance and prosperity of human civilization.
\end{abstract}

\section{Introduction}

The new millennium has ushered in the age of information revolution. Communication forms the back-bone of this revolution. Communication, an intrinsic need of all living beings, has found application since the inception of life on earth and continues to play an important role till today. Since human beings have conventionally been known to live in clusters known as societies, the term 'social beings' has increasingly come to be associated with them only. That however, by no means, implies that other living creatures are not social. It only means that human beings surely cannot afford to live in isolation. Since interacting in a social environment necessarily mandates the effective usage of communication skills, no wonder then, communication has emerged as the nervous system of any societal structure. This is true for the other levels of communication as well such as group communication and interpersonal communication. Just as the human body is rendered useless without the nervous system, any society necessarily requires the presence of an effective communication system to function at the optimum level. But then, the mere presence of a communication system is not going to be of much help. Just as being healthy necessarily pre-requisites the presence of both healthy body and healthy mind, the building of a healthy societal structure necessarily entails the need for a healthy communication system. By 'healthy communication system' is meant 'a communication system that thrives on the tenets of liberty, equality, justice and is driven by the aspirations of fraternity, unity and integrity of the society, the nation and the world as a whole'.

(c) 2015 Bhattacharyya; licensee Springer. This is an Open Access article distributed under the terms of the Creative Commons Attribution License (http://creativecommons.org/licenses/by/4.0), which permits unrestricted use, distribution, and reproduction in any medium, provided the original work is properly credited. 
Communication, being a powerful medium of persuasion, capable of exerting considerable influence on human beings, ought to be approached with a sense of restraint that is likely to act as a deterrent on the part of the exerciser from exercising its regressive potential. This very idea was echoed by the Macbride Commission in its landmark report, entitled Many Voices One World brought forth in the public domain in 1980, in the following words:

"Communication can be an instrument of power, a revolutionary weapon, a commercial product, or a means of education; it can serve the ends of either liberation or of oppression, of either the growth of the individual personality or of drilling human beings into uniformity. Each society must choose the best way to approach the task facing all of us and to find the means to overcome the material, social and political constraints that impede progress (UNESCO, 1980, p. 253)".

It has been over thirty years since the august jury had given its unequivocal verdict. However, we still seem to have been unable to overcome the material, social and political constraints towards effectively using communication for ensuring progress. One of the primary reasons behind this has been the increasing commercialization of communication in the global scenario in the name of liberalization, privatization and globalization (LPG). Under such circumstances, it has become the pressing need of the hour to revisit the basic approach towards understanding the communication phenomenon and shift our focus from viewing communication primarily as a profit-driven enterprise to the formulation and implementation of a value-based communication system. This necessarily calls for looking into relevant views from the stand-point of philosophical perception of communication as may be perceived from the wisdom of various religious texts that have shaped the views of human beings for generations. The present work is a humble endeavour towards exploring the possibility of conceptualizing the broad framework of such a valuebased communication system in the light of an understanding of certain basic principles envisaged in two world religions, Hinduism and Islam, which bear significant relation to the concept of human communication per se.

\section{Communication, culture and religion}

Now, let us come to the question of why do we need to seek refuge to our religious texts or for that matter, religion, to formulate a value-based communication system? Religion encompasses a belief-oriented approach towards community specific practice that binds the given cultural system together. Since communication acts as the thread that strings any cultural system together and religion moulds the perception of any individual in any cultural set-up which later finds expression through communication, the concepts of communication, culture and religion are invariably found be interrelated to one another.

As Alfred G. Smith (1966) wrote in his preface to Communication and Culture, culture is a code we learn and share, and learning and sharing require communication. Communication requires coding and symbols that must be learned and shared. Godwin C. Chu (1977) observed that every cultural pattern and every single act of social behavior involve communication. To be understood, the two must be studied together. Culture cannot be known without a study of communication, and communication can 
only be understood with an understanding of the culture it supports (York University, 2003, p. 29). This relationship is manifested even further when we talk of conceptualizing a value-based communication system as the very idea of value-inculcation in an individual emanates from the influence of culture upon him/her that so very often is shaped by his/her religious beliefs rather than any rule of law. This value-inculcation, in the long run, gives way to distinct communication behaviour patterns as well.

It is no secret that religions have acted as the lighthouse for human civilization since the ancient times. When there were no written laws, human beings looked upon religion as their only hope and frequently sought recourse to the same whenever they could not find any possible solutions. We also know that most world religions such as Hinduism, Islam, Christianity, Buddhism, Jainism, Sikhism, Judaism give due emphasis upon the exercise of human values such as love, tolerance, honesty and so on by their followers. This is because the welfare of any group fundamentally rests upon the exercise of human values by the individuals both within the members of the group and in interaction with members from other groups. Besides, the exercise of human values also exudes a sense of peace and goodness amongst individuals which in itself is so very important to enjoy the bliss of human living which alongside collective welfare is the ultimate goal of most world religions. When these human values find application through behavioural expressions in human beings, it gives way to the formation of a value-based communication system which in essence is a subtle combination of both individualism and collectivism.

Contemporary people are often said to have been extensively "globalized" by the Westcentric ideology of science and technology and lost their traditional religionconsciousness. "Today", however, "far from being buried in the dustbin of history, religion is making a comeback. Contemporary religious revival is not restricted to any one religion. It has become a universal phenomenon" (Bakar 1997, p. 3) (Ishii, 2008, p. 136). Recently, the growing significance of systematically studying interreligious communication, which has long been somehow neglected by intercultural communication scholars and educators, has come to be asserted as a newly rising intercivilizational and interreligious religio-ethical communication paradigm (Ishii, 2008, p. 139). "Apparently, religion plays deeply influential roles in the building of the most fundamental and latent parts of culture, such as attitudes, beliefs, cognition, values, and worldviews" (Ishii 2008, p. 17); (Ishii, 2006, p. 135).

In planning and practically conducting interreligious communication studies, (Cheng's 1997, pp. 126-129) five principles are worth considering (Ishii, 2008, p. 139):

$\triangleright$ Principle 1: To recognize historical differences and appreciate cultural diversity.

$\triangleright$ Principle 2: To observe nondominance and mutual respect and mutual care.

$\triangleright$ Principle 3: To converge into the great ultimate and infinite truth.

$\triangleright$ Principle 4: To hold the belief in equal access and mutual enrichment.

$\triangleright$ Principle 5: To develop creative advancement and mutual transformation.

\section{Towards a synergy between Hindu and Islamic perspectives}

While there remain many approaches towards the conceptualization of a value-based communication system from different perspectives that different world religions offer us through their pearls of wisdom, in the present work, we shall limit ourselves to the study of certain basic concepts from the standpoint of two world religions only: Hinduism 
and Islam. The reason behind such a choice is simple indeed. While the two religions in question are generally projected as propounding conflicting views on various concerns by zealots, the present work will seek to establish that at least on the question of formulating a value-based communication system, both the religions lay down similar tenets, viz., truth, justice, equity, restraint, selflessness, detachment for its followers that are likely to find relevance in the modern-day communication dynamics. On a greater note of optimism, it is also hoped that the work shall be able to contribute towards bringing together communication scholars across the globe from these two great traditions respectively in putting aside the unpleasant remnants of the past and walking hand in hand for realizing the cherished ideal of universal harmony in the present and the future.

The principles of Hinduism have come into existence in principal from a collection of texts known as the Vedas. It is widely regarded that the Rgveda is the oldest available text of the Indian civilization which is followed by the other three Vedas, Yajurveda (The Book of Rituals), Sämaveda (The Book of Songs), and Atharvaveda (The Book of Applications). The Vedas are supposed to be apaurușeya, that is, not attributable to human beings. While it is questionable as to how a book could have come into existence without human intervention, what is equally questionable is how could have one human being written or compiled such a huge volume of antiquity. This dilemma of the modern-day thinking man was perfectly addressed by Swami Vivekananda in his speech on Hinduism delivered at the World's Parliament of Religions in Chicago in September, 1893. Swamiji explained the mystery of the Vedas in the following words:

"The Hindus have received their religion through revelation, the Vedas. They hold that the Vedas are without beginning and without end. It may sound ludicrous to this audience, how a book can be without beginning or end. But by the Vedas no books are meant. They mean the accumulated treasury of spiritual laws discovered by different persons in different times (Vivekananda Study Circle, IIT Madras, p. 8)".

However, the principles of Hinduism have come down to the modern civilization through the process of 'presentation through simplification for generalization' known as sädhäranikaraṇa $a^{\mathrm{a}}$. Thus, while the Vedas are regarded as the root source of every Hindu principle, the essence of the principles has been explained to the aftergenerations through the later scriptures such as the Purānas, the Upanișads, the Dharmaśästras, the later commentaries by various scholars and also extant literature such as the Rāmāyana, the Mahäbhärata and the Bhagavad Gïtā.

The principles of Islam, on the other hand, are attributed to the holy book known as the Qur'an which is the central book of Islam. Interestingly enough, the Qur'an too is considered to be a direct revelation by God just as the Vedas except for the fact that the Muslims believe that the Qur'an was revealed by God Himself to one singular person, the founder of Islam, Prophet Mohammad through God's angel. The Qur'an is a book of chapters, 114 chapters in all, consisting of verses. The chapters are called Suräs and the verses are called Āyah (Plural: Āyāt).

What is striking here is the fact that both the sacred texts, the Vedas and the Qur'an, initially came down to us through the oral tradition and were recorded in written form later on by the followers of the respective religions. Let us now focus 
on the basic human values that both these religions advocate for which are essential for the conceptualization of a value-based communication system in the present scenario.

\section{The principle of truth}

The principle of truth is central to both Hinduism and Islam. The national motto of India, Satyameva Jayate, has been taken from the following mantra from the Mundaka Upanișad which is a sacred scripture of the Hindus:

$\triangleright$ satyameva jayate nānrtam satyena panthā vitato devayānah | yenäkramantyrșayo hyāptakāmā yatra tatsatyasya paramam nidhānam || 3.1.6 (Lokeswarananda, 1994, p. 107)

Translated to English, the mantra implies:

Truth alone prevails, not untruth, for the broad path to heaven runs through truth. The sages who have overcome desires attain that goal which truth leads to (Lokeswarananda, 1994, p. 108).

Similar echoes are also found in the certain verses of the Qur'an. Olayiwola (1993) cites a couple of such Qur'anic ayahs that "indicate that people are enjoined to be conscientiously truthful, to develop the spirit and activity of truthfulness by upholding the cause of truthfulness and by loving the company of those who are genuinely truthful. Truthfulness in thought, word and deed is, therefore, an Islamic obligatory duty in interpersonal communication and relationships (Olayiwola, 1993, p. 99)". According to the Qur'an, Allah says:

$\triangle$ And cover not Truth with falsehood, nor conceal the Truth when ye know [what it is]. 2: 42 (Ali, 1987, p. 3)

$>$ And say: "Truth has [now] arrived, and Falsehood perished: for Falsehood is [by its nature] bound to perish." 17: 81 (Ali, 1987, p. 136)

$\triangleright$...shun the word that is false... 22: 30 (Ali, 1987, p. 162)

$>$ Shall I inform you, [O people!], on whom it is that the evil ones descend? They descend on every lying, wicked person. 26: 221, 222 (Ali, 1987, p. 185)

As we know, the principle for truth is of paramount importance in communication. Truthfulness alone can lead to the building of an environment of trust and confidence which ultimately strengthens human relationships. While individuals need to be truthful in all their communicative endeavours, being truthful is even more essential when it comes to crisis communication.

Honesty leaves no burden on your shoulders. Trying to cover up a problem can only lead to the media's search to find the truth. Dishonesty can create damage to your organization's good reputation with your community. Relaying through the media that the problem is evident and being corrected is the best way to maintain an organization's good standing throughout times of crisis (Florida Redevelopment Association, 2010, p. 64). 


\section{The principle of justice}

The second important principle to both Hinduism and Islam is that of justice. Justice is a primary requisite of any societal order and both the religions have given considerable importance to justice.

According to the Manusmrti, an ancient Indian text that lays down the code of desirable social conduct for human beings, the sanctity of Justice must always be upheld. Thus states the text:

$\triangleright$ dharma eva hato hanti dharmo rakshati rakshitah | tasmätdharmo na hantavyo mā no dharmo hato'vdhit || (Chapter VIII; Verse 15)

Translated to English, the verse implies:

$\triangleright$ Justice, being violated, destroys; justice, being preserved, preserves: therefore justice must not be violated, lest violated justice destroy us (Bühler, 1886, p. 255).

The concept of justice is also found in the Qur'an.

Allah commands justice, the doing of good, and liberality to kith and kin, and $\mathrm{He}$ forbids all shameful deeds, and injustice and rebellion: He instructs you, that ye may receive admonition. 16:90 (Ali, 1987, p. 129)

$\triangleright$ O ye who believe! Stand out firmly for justice, as witnesses to Allah, even as against yourselves, or your parents, or your kin, and whether it be [against] rich or poor: for Allah can best protect both. Follow not the lusts [of your hearts], lest ye swerve, and if ye distort [justice] or decline to do justice, verily Allah is well-acquainted with all that ye do. 4: 135 (Ali, 1987, p. 44)

In this regard, Olayiwola (1993) asserts:

"The first Islamic principle of interpersonal communication, human interaction and relationship is justice. People are enjoined to ensure that their interpersonal communication and relationships are governed by justice, whether such interpersonal communication is between the ruler and the ruled, rich and poor, husband and wife, parents and children, Muslims and non-Muslims, even if the application of justice will be against themselves or their kith and kin (Olayiwola, 1993, p. 97)".

The concept of social justice has emerged as a major area of concern in the new millennium. The media has a responsibility to the masses and that is to be conscious and responsive to their needs and aspirations. This responsibility cannot be fulfilled unless the media is conscious of its duty of social justice and can act without fear or favour. The role of the media in developing countries is of particular importance as the media has the responsibility of standing up as the voice of the voiceless instead of giving into the hands of the vested interests. However, the principle of justice in communication perspective is not limited only to the media. People, in general, need to be guided by the principle of justice in communication practices. 


\section{The principle of equity/righteousness}

The third principle that is central to both Hinduism and Islam is that of equity or righteousness. According to the Manusmrti:

$>$ Neither a man who (lives) unrighteously, nor he who (acquires) wealth (by telling) falsehoods, nor he who always delights in doing injury, ever attain happiness in this world (Bühler, 1886, p. 155). (Chapter IV; Verse 170)

$>$ Let him, though suffering in consequence of his righteousness, never turn his heart to unrighteousness; for he will see the speedy overthrow of unrighteous, wicked men (Bühler, 1886, p. 155). (Chapter IV; Verse 171)

$>$ Unrighteousness, practised in this world, does not at once produce its fruit, like a cow; but, advancing slowly, it cuts off the roots of him who committed it (Bühler, 1886, p. 155). (Chapter IV; Verse 172)

$>$ He prospers for a while through unrighteousness, then he gains great good fortune, next he conquers his enemies, but (at last) he perishes (branch and) root (Bühler, 1886, p. 156). (Chapter IV; Verse 174)

Islam condemns lying, dishonesty, deceit, untrustworthiness, hypocrisy, envy, hatred and miserliness in interpersonal communications and relationships (Olayiwola, 1993, p. 98). Allah says:

$>$ If any do deeds of righteousness,- be they male or female - and have faith, they will enter Heaven, and not the least injustice will be done to them. 4:124 (Ali, 1987, p. 43)

$>$ To those who do right is a goodly [reward]- Yea, more [than in measure]! No darkness nor shame shall cover their faces! they are companions of the garden; they will abide therein [for aye]! 10:26 (Ali, 1987, p. 95)

$>$ Wealth and sons are allurements of the life of this world: But the things that endure, good deeds, are best in the sight of thy Lord, as rewards, and best as [the foundation for] hopes. 18: 46 (Ali, 1987, p. 140)

$\triangleright$ "And Allah doth advance in guidance those who seek guidance: and the things that endure, Good Deeds, are best in the sight of thy Lord, as rewards, and best in respect of [their] eventual return." 19: 76 (Ali, 1987, p. 147)

While it may be argued that the sense of equity or righteousness is a matter of subjective perception, the general idea behind the principle of equity or righteousness remains to be the attainment of the desired state of being able to maintain both individual bliss and collective welfare. Thus, a man or media will always face concerns of survival, sustenance and prosperity but then, he/it must be conscious of the path taken and the acceptance of the path in a civilized society.

\section{The principle of restraint}

There was a time when the media had no voice at all. But today, things are different. The media today has power next to virtually none. But then, great power is necessarily accompanied by great responsibility. Thus, the media must speak up for what is just 
and speak up against whatever is unjust in an unequivocal manner. However, it ought to do so with a sense of restraint. Practising restraint does not mean accepting what is unjust. It only means being responsive to the situation and expressing one's views with wise discretion. The concept of restraint in public speaking has been touched upon both in Hinduism and Islam alike.

Thus is said in the Manusmrti:

$\triangleright$ satyam bruyāt, priyam bruyāt; na bruyāt satyam apriyam | priyam cha nānṛtạ̣ bruyāt; esha dharmah sanātanah || (Chapter IV; Verse 138)

Translated to English, it means, "A man must always speak the truth; he must always speak the pleasant. However, there are exceptions to these universal rules as well. A man must not speak the truth that however true is unpleasant to the world in general and he must not also speak anything pleasant that, however pleasant, is untrue. This is the path of the eternal morality".

The Qur'an also says:

$>$ Allah loveth not that evil should be noised abroad in public speech, except where injustice hath been done; for Allah is He who heareth and knoweth all things. 4: 148 (Ali, 1987, p. 44)

$\triangleright$ O ye who believe! Let not some men among you laugh at others: It may be that the [latter] are better than the [former]: Nor let some women laugh at others: It may be that the [latter are better than the [former]: Nor defame nor be sarcastic to each other, nor call each other by [offensive] nicknames: Ill-seeming is a name connoting wickedness, [to be used of one] after he has believed: And those who do not desist are [indeed] doing wrong. 49:11 (Ali, 1987, p. 262)

\section{The principle of service/selflessness and social welfare}

From the Hindu perspective, the principle of social welfare is best exemplified by the doctrine of Shiva Jũāne Jiva Sevā as envisaged by Swami Vivekananda. Swami Vivekananda was the first religious leader in India to speak for the poor and the downtrodden and to state boldly, 'He who sees Shiva in the poor, in the weak and the diseased, really worships Shiva; and ... with him Shiva is more pleased than with the man who sees Him only in temples.' It was Swamiji who coined the word daridra-nārāyaṇa to refer to the poor (Belur Math). Since man is potentially Divine, service to man is indeed service to God. Instead of looking upon a needy person as an object of pity, he is looked upon as an object of worship. Such an attitude elevates both the giver and the recipient (Belur Math).

The principle of selflessness from the Islamic perspective can be drawn from the views given in the Hadith ${ }^{\mathrm{c}}$ :

$\triangleright$ "None of you will have faith till he wishes for his (Muslim) brother what he likes for himself." (McLean, p. 10)

$\triangleright$ "...whosoever is saved from the covetousness such are they who will be successful." (McLean, pp. 923-924)

$\triangleright$ "By no means shall you attain righteousness unless you spend (in charity) of that which you love." (McLean, p. 1161) 
Regarding the principle of selflessness in Islam, Olayiwola (1993) asserts:

"For Muslims, the nature of their commitment to Allah and their responsibilities toward their mission as well as toward fellow human beings, demands that they should be ready to offer sacrifices in terms of their time, wealth and other possessions. A true understanding of the sender, message, channel, receiver and effect of communication in Islam makes it quite clear that preferring others above one's own self facilitates interpersonal relationships as well as interpersonal communication (Olayiwola, 1993, p. 101)."

\section{The principle of detachment}

No individual can remain attached to worldly pleasures and commit himself/ herself to social welfare. Thus, the principle of social welfare is integrally related to the principle of detachment. Both Hinduism and Islam advocate for the practice of detachment in mundane life for a person who cannot remain detached to worldly pursuits is always likely to remain discontented irrespective of whatever or however much he/she might achieve.

According to the Qur'an:

$>$ Do not covet what God has given to some of you more than others- men have the portion they have earned; and women the portion they have earned- you should rather ask God for some of His bounty: He has full knowledge of everything. 4:32 (Haleem, 2005, pp. 53-54)

The principle of detachment is closely related to 'observance of the spirit of contentment (Olayiwola, 1993, p. 99)'. In this regard, Olayiwola (1993) asserts:

"Islam enjoins contentment in interpersonal relationships. Discontentment can be in respect of one's resources or one's possessions. For instance, someone may feel that if he is able to acquire the patronage of the high-ups in interpersonal relationships, he can increase his resourcefulness, for increasing his possession: wealth, prestige, power etc. Such an ambition leads almost always to debasement of the self, and consequently, to the violation of the virtue of self-respect in interpersonal communication. Hence, a Muslim has been commanded to direct all his needs and all his ambitions to God and God alone (Olayiwola, 1993, p. 99)."

From the Hindu perspective, the principle of detachment is best exemplified in the idea of Nishkāma Karma as found in the Bhagavad Gïtā. As Lord Sri Krishna tells Arjuna in the Bhagavad Gïtā:

$>$ You have a right to perform your prescribed duty, but you are not entitled to the fruits of action. Never consider yourself the cause of the results of your activities, and never be attached to not doing your duty (The Bhaktivedanta Book Trust International, Inc.) d. $^{\text {. }}$

It is the theory of non-attachment, to be attached to nothing while doing our work of life. Know that you are separated entirely from the world; that you are in the world, 
and that whatever you may be doing in it, you are not doing that for your own sake. Any action that you do for yourself will bring its effect to bear upon you. If it is a good action you will have to take the good effect, and, if bad, you will have to take the bad effect; but any action that is done for your own sake, whatever it be, will have no effect on you (Vivekananda Study Circle, IIT Madras, p. 74).

\section{Concluding remarks}

The exercise of communication in today's world is unfortunately seen as an endeavour harping on either individualism or collectivism. By individualism is meant having a self-centric view of any endeavour. Since the communication has been largely perceived as a profit driven endeavor, the focus is always on the maximization of profits from the functional endeavour. However, communication ought not to be seen as an instrument of material accomplishment. Rather, it is to be seen as a path of selfless action that leads to the welfare of the world and, in the process, also gives the individual the scope to enjoy the bliss of living through the attainment of inner peace. That alone can lead to the salvation of the self and the welfare of the world as exemplified from the concept of ätmano mokshärtham jagat hitāya cha as envisaged by Swami Vivekananda.

That communication is a non-dualist exercise is evident from the above discussion. It is worth mentioning here that a human mind can only contribute to universal welfare if it enjoys inner peace. At the same time, the mind can be completely at peace only if everything around him is in perfect order. That is the golden rule ${ }^{\mathrm{e}}$ of the cosmos. It is this golden rule that is at the heart of viewing communication as an activity not exclusive to the self. It is, rather, an act of fulfillment of both individual joy and universal welfare through the realization of the non-dualism of the human mind and the universe where both the mind and the universe contribute to the fulfillment of each other's ultimate purpose. In viewing communication in such a non-dualistic approach remains our hope towards ensuring the survival, sustenance and prosperity of human civilization.

Here, I would like to focus a bit more on the concept of non-dualism in the communication perspective. Non-dualism essentially refers to the concept of the unity of the universe or the Supreme Consciousness or God being the source of everything. Here, it may be argued: What is the point of seeking to establish unity with something that is largely unperceivable to ordinary individuals? Keeping that in mind, let it be put in this way. The concept of universe being a whole and the earth and its individuals being a part of it has already been established by both Science and Philosophy. As far as the idea of Supreme Consciousness or God being the source of everything is concerned, it is true that such a realization has been attained by only few individuals in the history of human civilization. But then, let us put it this way. Every individual is conscious of the existence of two entities: the individual and the physical world. Thus, every individual may perceive at least two suppositions:

1. I exist, therefore, the world exists.

2. The world exists, therefore, I exist.

Therefore, we only have to establish the connection between the individual and the world. This is easy to explain. Each individual is a part of the physical world and draws his sensory experiences from the manifestations in the physical world. On the other hand, the total activism in the physical world is only a sum total of the individual 
activisms exerted by the individuals in everyday life. While positive individual activisms ensure collective welfare, negative individual activisms result in an environment of disharmony and chaos. Thus, we find that the concepts of individualism and collectivism are not exclusive in nature. They are, rather, complementary concepts which work in tandem towards ensuring the harmony of the world. The primary purpose of communication being establishing a network of interactions among individuals, this idea of nondualism of the individual and the world perfectly fits into our understanding of the mechanism of human communication and, hence, deserves universal acceptance.

While there remain many other possibilities of exploration for the furtherance of the conceptualization of a value-based communication system from diverse religious perspectives, the present study is limited to putting forth only six basic principles from the stand-point of only two world religions, Hinduism and Islam, which are fundamentally related to the concept of a healthy communication system that thrives on the tenets of liberty, equality, justice and is driven by the aspirations of fraternity, unity and integrity of the society, the nation and the world as a whole. That having said, the conceptualization of such a system is not limited to the exploration from the standpoint of only the concerned religious scriptures. More possibilities are likely to come to the fore from the exercise of these religions by their followers in their daily lives.

At least at a basic "thin" morality level, some commonalities exist between Asia and the West. In addition, as many have pointed out, whatever the degree to which they divided humankind, the world's major religions-Western Christianity, Orthodoxy, Hinduism, Buddhism, Islam, Confucianism, Taoism, Judaism-also share key values in common. If humans are ever to develop a universal civilization, it will emerge gradually through the exploration and expansion of these commonalities. Thus, in addition to the abstention rule and the joint mediation rule, the third rule for peace in a multicivilizational world is the commonalities rule: peoples in all civilizations should search for and attempt to expand the values, institutions, and practices they have in common with peoples of other civilizations (Huntington, 1993, p. 29).

In the 1950s, Lester Pearson warned that humans were moving into "an age when different civilizations will have to learn to live side by side in peaceful interchange, learning from each other, studying each other's history and ideals and art and culture, mutually enriching each others' lives. The alternative, in this overcrowded little world, is misunderstanding, tension, clash, and catastrophe". The futures of both peace and Civilization depend upon understanding and cooperation among the political, spiritual, and intellectual leaders of the world's major civilizations... In the greater clash, the global "real clash," between Civilization and barbarism, the world's great civilizations, with their rich accomplishments in religion, art, literature, philosophy, science, technology, morality, and compassion, will also hang together or hang separately (Huntington, 1993, p. 31).

With the present age of information revolution being plagued by issues of materialism, consumerism and power struggles, human race finds itself in a helpless situation where it can neither do away with technological innovations nor control its adverse effects. Under such circumstances, the understanding and implementation of a valuebased communication system remains our only hope towards nullifying the prospects of technological determinism. However, this cannot possibly be done without tapping into the rich tapestry of wisdom that world religions have to offer us. The author's only interest lies in drawing the attention of fellow researchers into the umpteen number of 
possibilities that various world religions can offer to the realization of such a desired order and it is hoped that this humble endeavour of his will encourage others to seek more such possibilities and bring them to light in the days ahead.

\section{Endnotes}

aTaking cue from sage Bharata's Nāṭyaśāstra on conditions of concord (samprīi/ bonhomie, superior knowledge and skill of the communicator, swahṛdaya/same mindedness, Rasa-Utpatti/ surge of emotion and mood uplift) between the communicator (performer) and the communicatee (audience) emerges the perspective of Sādhāranikarana. Fitting communicator's message into the content need of the communicatee on the strength of communicator stepping into the shoe of the communicatee from a higher level of knowledge and skill but with swahṛdaya and sampriiti for expression is the crux of the perspective which I.P. Tiwary, J.S. Yadava and recently N.M. Adhikary and K.K. Bhattacharyya have worked upon. This perspective of communication takes into consideration several quotients of the transcending phenomenon. These are culture of the communicatee, physiological and physical basis (Rasa, emotion, expressions of different moods as cues for the communicatee), and the mindset of an equal despite having higher knowledge and skill on the part of the communicator. Presence of these quotients uplifts communication to a superior level of functionality (LohoChoudhury, 2014). According to the present author, sädhäranikarana refers to 'establishing commonness among the participants of a communication process through the process of simplification' (Bhattacharyya, 2013, p. 72).

bet him say what is true, let him say what is pleasing, let him utter no disagreeable truth, and let him utter no agreeable falsehood; that is the eternal law (Bühler, 1886, p. 150).

${ }^{c}$ The word Hadith means news, story, communication, conversation, report. In the Islamic religious context, it means an individual report of an action, instruction or saying, of the Prophet, or his approval, disapproval, or silence (tacit approval) regarding some matter or action. By its very nature, the reliability of Hadith reports is dependent on the understanding by the reporter of the context and of the words and their applicability. Regardless of the complexity, however, Hadith is the second primary source of Islamic guidance (Shafi, $p .1$ ).

${ }^{\mathrm{d}}$ karmanyevādhikäraste mā phaleșu kadāchana | mā karmaphalaheturbhur mā te samgo'stvakarmaṇi || (Bhagavad Gïtā: Chapter 2, Verse 47)

${ }^{\mathrm{e}}$ The Golden Rule or the ethic of reciprocity is found in the scriptures of nearly every religion. It is often regarded as the most concise and general principle of ethics (Wilson, 1991, p. 206). Some of the assertions regarding the Golden Rule in the scriptures of different religions are given below:

$>$ You shall love your neighbor as yourself. (Judaism and Christianity. Bible, Leviticus 19.18) (Wilson, 1991, p. 206)

$>$ Whatever you wish that men would do to you, do so to them. (Christianity. Bible, Matthew 7.12) (Wilson, 1991, p. 206)

$>$ Not one of you is a believer until he loves for his brother what he loves for himself. (Islam. Forty Hadith of an-Nawawi 13) (Wilson, 1991, p. 206) 
$\triangle$ A man should wander about treating all creatures as he himself would be treated. (Jainism. Sütrakrtānga 1.11.33) (Wilson, 1991, p. 206)

$>$ Try your best to treat others as you would wish to be treated yourself, and you will find that this is the shortest way to benevolence. (Confucianism. Mencius VII.A.4) (Wilson, 1991, p. 206)

$>$ One should not behave towards others in a way which is disagreeable to oneself. This is the essence of morality. All other activities are due to selfish desire. (Hinduism. Mahābhärata, Anuśäsana Parva 113.8) (Wilson, 1991, p. 206)

$>$ Tsekung asked, "Is there one word that can serve as a principle of conduct for life?" Confucius replied, "It is the word shu-reciprocity: Do not do to others what you do not want them to do to you." (Confucianism. Analects 15.23) (Wilson, 1991, p. 206)

$>$ Comparing oneself to others in such terms as "Just as I am so are they, just as they are so am I," he should neither kill nor cause others to kill. (Buddhism. Sütta Nipāta 705) (Wilson, 1991, p. 207)

$>$ One going to take a pointed stick to pinch a baby bird should first try it on himself to feel how it hurts. [African Traditional Religions. Yoruba Proverb (Nigeria)] (Wilson, 1991, p. 207)

$>$ One who you think should be hit is none else but you. One who you think should be governed is none else but you. One who you think should be tortured is none else but you. One who you think should be enslaved is none else but you. One who you think should be killed is none else but you. A sage is ingenuous and leads his life after comprehending the parity of the killed and the killer. Therefore, neither does he cause violence to others nor does he make others do so. (Jainism. Ācārānga Sütra 5.101-2) (Wilson, 1991, p. 207)

As far as agnostics or atheists are concerned, it would be unfair to assume that they would outrightly reject the golden rule. Going by the logic that they place rationality and empiricism as the basis for all their beliefs, it is likely that they shall arrive at similar conclusions as echoed by the golden rule through trial-and-error method over a period of time through the practical application of the golden rule in physical world.

${ }^{\mathrm{f}}$ Though the concept of non-dualism may be contested as far as Islam is concerned, the concept of Tawhid seems to come close to the former.

Literally Tawhïd means "unification" (making something one) or "asserting oneness," and it comes from the Arabic verb wahhada which itself means to unite, unify, or consolidate. However, when the term Tawhì is used in reference to Allah (i.e. Tawhìdulläh), it means realizing and maintaining of Allah's unity in all of man's actions which directly or indirectly relate to Him (Philips, 2005, p. 17).

Competing interests

The authors declare that they have no competing interests.

\section{Acknowledgement}

The author would like to acknowledge his gratitude to Dr. Sanjit Bhattacharya, Sanskrit Teacher at the Sanskrit Collegiate School, Kolkata, West Bengal, India for being kind enough to go through the work and help him with the modern transliteration system of the Sanskrit language. 
Belur Math. n.d. Ideology of Ramakrishna Math and Ramakrishna Mission. Retrieved January 12, 2014, from http:// www.belurmath.org: http://www.belurmath.org/ldeology.htm

Bhattacharyya, Kapil Kumar. 2013. Science communication in the Indian perspective: Insights from the Indian experience. Indologica Taurinensia: The Online Journal of the International Association of Sanskrit Studies XXXIX: 67-82.

Bühler, Georg. 1886. The laws of Manu translated with extracts from seven commentaries. Oxford: Clarendon Press.

Cheng, Chung-Ying. 1997. Confucianism and Islam as two major postmodern resources of humanity and cohumanity. In Islam and confucianism: A civilizational dialogue (pp. 119-130), ed. O Bakar and GN Cheng. Kuala Lumpur: University of Malaya Press.

Chu, Godwin C. 1977. Radical change through communication in Mao's China. Honolulu, HI: University Press of Hawaii.

Florida Redevelopment Association 2010. Crisis communication. Retrieved March 18, 2014, from http:// redevelopment.net: http://redevelopment.net/wp-content/uploads/2010/10/Manual-Crisis-Communication.pdf

Haleem, MASAbdel. 2005. The Qur'an. New York: Oxford University Press.

Huntington, Samuel Phillips. 1993. The Clash of Civilizations and the Remaking of World Order. Retrieved November 29, 2013, from http://www.stetson.edu: http://www.stetson.edu/artsci/political-science/media/clash.pdf

Ishii, Satoshi. 2006. Complementing contemporary intercultural communication research with East Asian sociocultural perspectives and practices. China Media Research 2(1): 13-20.

Ishii, Satoshi. 2008. Promoting interreligious communication studies: A rising rationale. Human Communication: A Publication of the Pacific and Asian Communication Association 11(No.1): 133-144.

LohoChoudhury, Biplab. 2014. Reviewing status of communication in India's contemporary health policy. Ahmedabad, Gujarat, India: Paper presented at the Annual Conference MICA ICMC 2014: Managing Health Communication: People, Programmes and Products.

Lokeswarananda, Swami. 1994. Mundaka Upanisad. Kolkata: The Ramakrishna Mission Institute of Culture.

McLean, Bill. n.d. Hadith. Retrieved April 25, 2014, from http://www.dic-chicago.org: http://www.dic-chicago.org/books/ SahihBukhari.pdf

Olayiwola, Abdur Rahman O. 1993. Interpersonal communication, human interaction and societal relationships in Islam. Africa Media Review 7(No. 3): 91-104.

Philips, Abu Ameenah Bilal. 2005. The fundamentals of Tawheed (2nd edition). Riyadh: International Islamic Publishing House. Shafi, Mohammad. n.d.. The HADITH - how it was collected and compiled. Retrieved 05 11, 2014, from http:// www.daralislam.org: http://www.daralislam.org/portals/0/Publications/TheHADITHHowitwasCollectedandCompiled.pdf Smith, Alfred G. 1966. Communication and culture. New York: Holt, Rinehart and Winston.

UNESCO. 1980. Many voices one world. Retrieved May 02, 2012, from http://unesdoc.unesco.org: http:// unesdoc.unesco.org/images/0004/000400/040066eb.pdf

Vivekananda Study Circle, IIT Madras. n.d.. Complete works of Swami Vivekananda Volume 1. Retrieved August 05, 2010, from http://www.vsc.iitm.ac.in: http://www.vsc.iitm.ac.in/Vivekananda/Complete\%20works/ Complete_Works_of_Swami_Vivekananda___Vol_1.pdf

Wilson, Andrew. 1991. World scripture: a comparative anthology of sacred texts. Retrieved March 19, 2015, from http:// understandingworldreligions.com: http://understandingworldreligions.com/content/books/World\%20Scriptures.pdf

York University. 2003. Defining communication as an element of culture. Retrieved April 18, 2014, from http:// www.yorku.ca: http://www.yorku.ca/wsywong/course/ysdn3104_04/jandt4echp2.pdf

\section{Submit your manuscript to a SpringerOpen ${ }^{\circ}$ journal and benefit from:}

- Convenient online submission

- Rigorous peer review

- Immediate publication on acceptance

- Open access: articles freely available online

- High visibility within the field

- Retaining the copyright to your article

Submit your next manuscript at $>$ springeropen.com 